\title{
The birds of Gag Island, Western Papuan islands, Indonesia
}

\author{
R.E. Johnstone \\ Western Australian Museum, Locked Bag 49, Welshpool DC, Western Australia 6986
}

\begin{abstract}
This report is based mainly on data gathered during a biological survey of Gag Island by a joint Western Australian Museum, Museum Zoologicum Bogoriense and Herbarium Bogoriense expedition in July 1997. A total of 70 species of bird have been recorded for Gag Island and a number of these represent new island and/or Raja Ampat Archipelago records. Relative abundance, status, local distribution and habitat preferences found for each species are described, extralimital range is outlined and notes on taxonomy are also given. No endemic birds were recorded for Gag Island but a number of species show significant morphological variation from other island forms and may prove to be distinct taxonomically
\end{abstract}

\section{INTRODUCTION}

Gag Island $\left(0^{\circ} 25^{\prime} \mathrm{S}, 129^{\circ} 53^{\prime} \mathrm{E}\right)$ is one of the Western Papuan or Raja Ampat Islands, lying just off the Vogelkop of Irian Jaya, between New Guinea and Halmahera, Indonesia. These islands include (from north to south) Sayang, Kawe, Waigeo, Gebe, Gag, Gam, Batanta, Salawati, Kofiau, Misool and a number of small islands (Figure 1). Gag Island is separated from its nearest neighbours Gebe Island to the north-west, and Batangpele Island to the north-east, by about $40 \mathrm{~km}$ of relatively deep sea. Gag Island is roughly oval shaped $12 \mathrm{~km}$ long by 7 $\mathrm{km}$ wide with its longest axis directed N-S and with a surface area of $56 \mathrm{~km}^{2}$ (Figure 1). The east coast is deeply indented by the shallow Gambir Bay, which penetrates about $1.5 \mathrm{~km}$ inland. Most of the coast is rocky but there are a number of sandy beaches on the northern and western sides. Gag Island consists mostly of undulating hills, the highest peak Gunung Susu rising to $311 \mathrm{~m}$. The island contains a number of small rivers and creeks including the Musawalo River in north and the Wapob River in east draining into Gambir Bay. Sago swamps and fresh water springs are abundant including a fairly large spring fed lagoon in the south-west corner. There is a small village on the north side of Gambir Bay and a number of residents at Kampung Tua on the northern coast. Domestic goats and domestic fowl occur throughout the cultivated areas and do not appear to have greatly disturbed the vegetation.

Gag Island was visited by the joint Western Australian Museum, Museum Zoologicum Bogoriense and Herbarium Bogoriense group between 9 and 20 July 1997. The major aim of the preliminary bird survey was to document the avifauna of the island and provide data on local distribution, status and habitat preferences. A small collection was also made of species that undergo geographic variation for taxonomic, morphological and genetic studies. The annotated checklist provided covers every species recorded, both historically and during this survey.

In the annotated list I summarise for each species its relative abundance (whether it is very common, common, moderately common, uncommon, scarce or rare), whether it feeds alone or in groups, status (a judgement on whether it is a vagrant, visitor or resident), habitat preferences and breeding season. Extralimital range is also briefly outlined and for those species that are recognised as undergoing geographical variation, taxonomic notes have been provided.

\section{Habitats}

Eleven major habitat types were recognised on Gag Island.

1. Marine. Includes coastal seas, stacks, reef flats and sandy and rocky shores.

2. Kebun. Cultivated areas, mainly coconut plantations but also banana, taro, breadfruit and mango etc (Figure 2).

3. Disturbed volcanic forest. Mostly secondary forest backing kebun in northern part of island (Figure 1).

4. Primary volcanic forest. Lowland rainforest covering most of the northern third of the island. Tall luxuriant forest with a variable canopy, $30-35 \mathrm{~m}$ with emergents to $45 \mathrm{~m}$. Dominant genera include Diospyros sp., Sterulia longifolia, Planchonella sp., Celtis philippensis, Tricalysia malaccensis, Canarium littorale and Champereia manillana (Figure 5).

5. Sago vegetation. Fairly extensive stands around Gambir Bay and along Wapob River.

6. Grassland. Includes airstrip, open grassy areas 


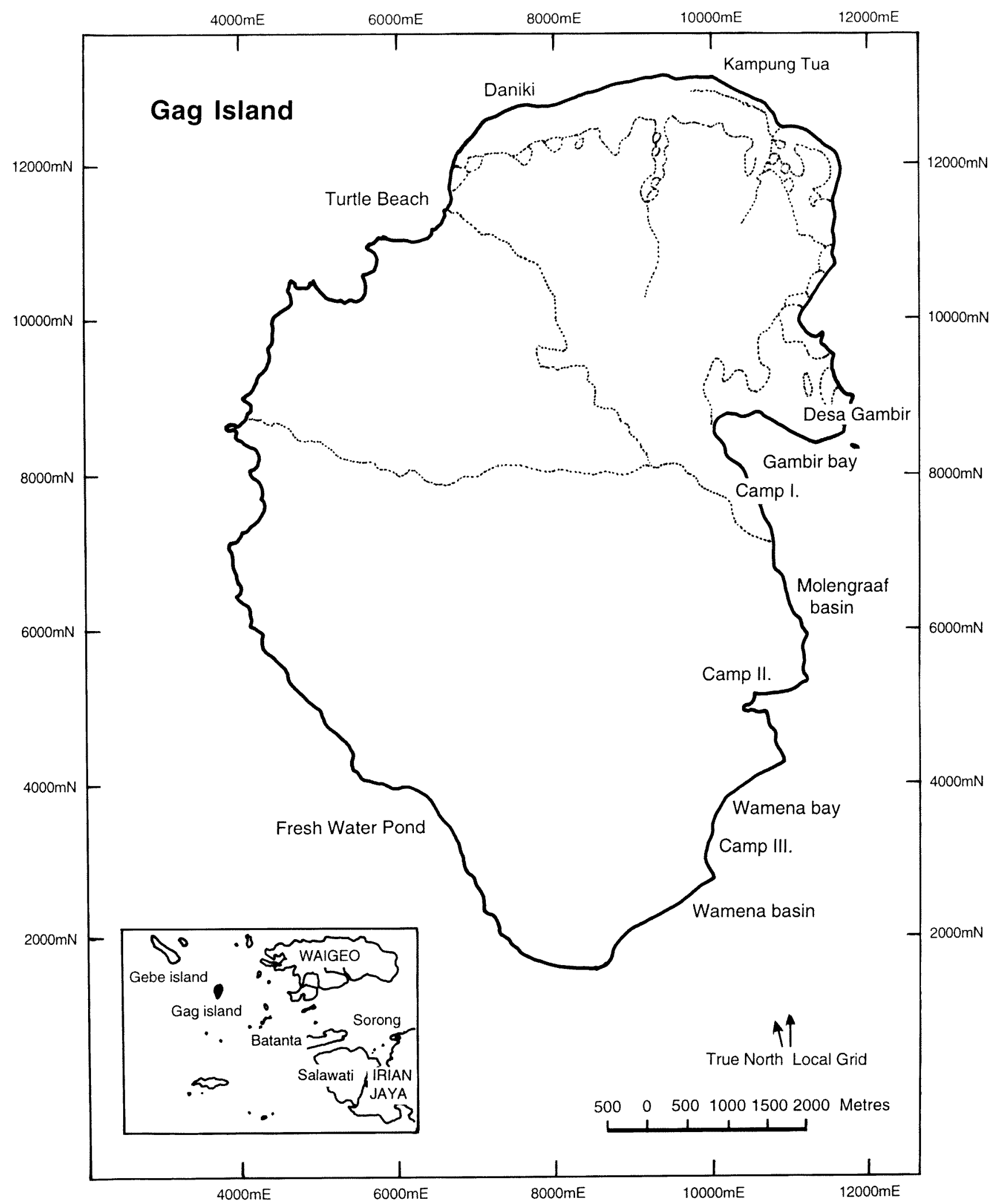

Figure 1 Map of Gag Island showing main features.

around settlements and grassy hills on the south-east corner of island. (Figures 1, 3 and 6).

7. Mangroves. Small stand of mangroves occurs at mouth of a creek at Camp Two (south-east side of island). Genera include Sonneratia, Lumnitzera, Ceriops, Bruguiera, Xylocarpus, Rhizophora and Exoecaria.
8. Beach vegetation. Ranging from dense closed forest to open disturbed or partly cultivated areas. Dominant plants include Barringtonia, Calophyllum, Casuarina, Scaevola, Pandanus, Tournefortia, Trema, Flagellaria, Hibiscus and Terminalia (Figure 7). 


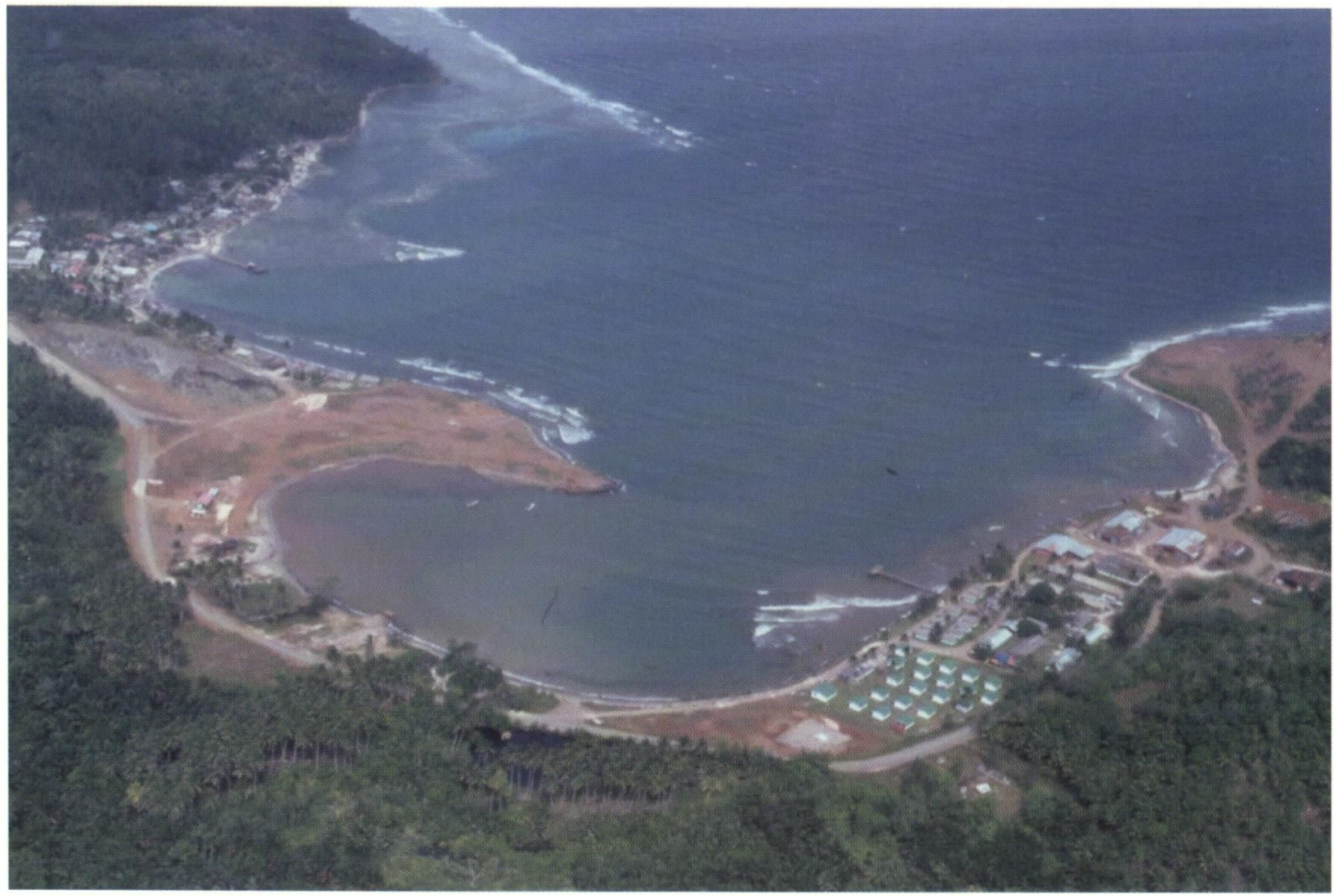

Figure 2 Gambir Bay, with BHP Camp on right and village backed by kebun on left.

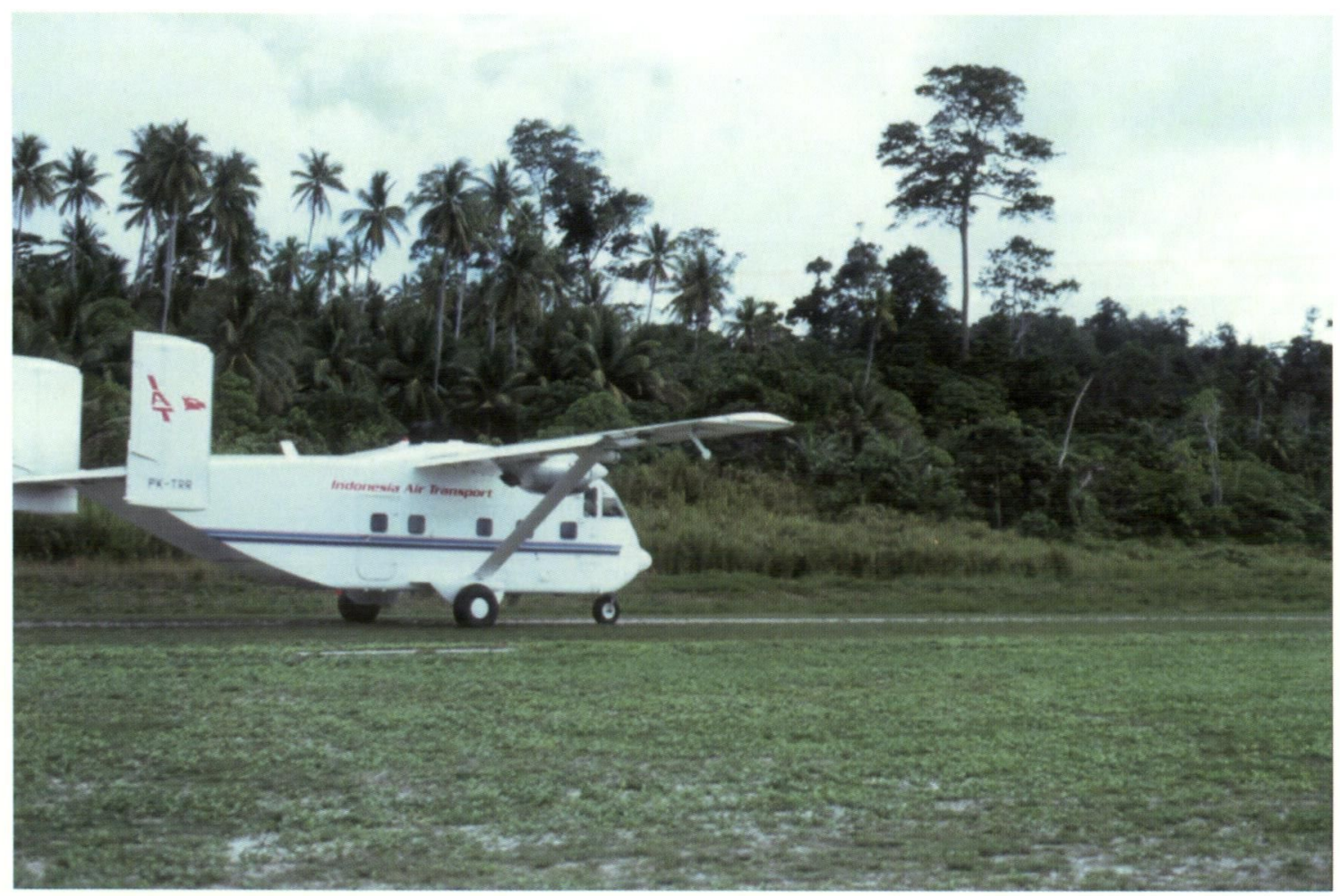

Figure 3 Airstrip with rank herbage and kebun. 


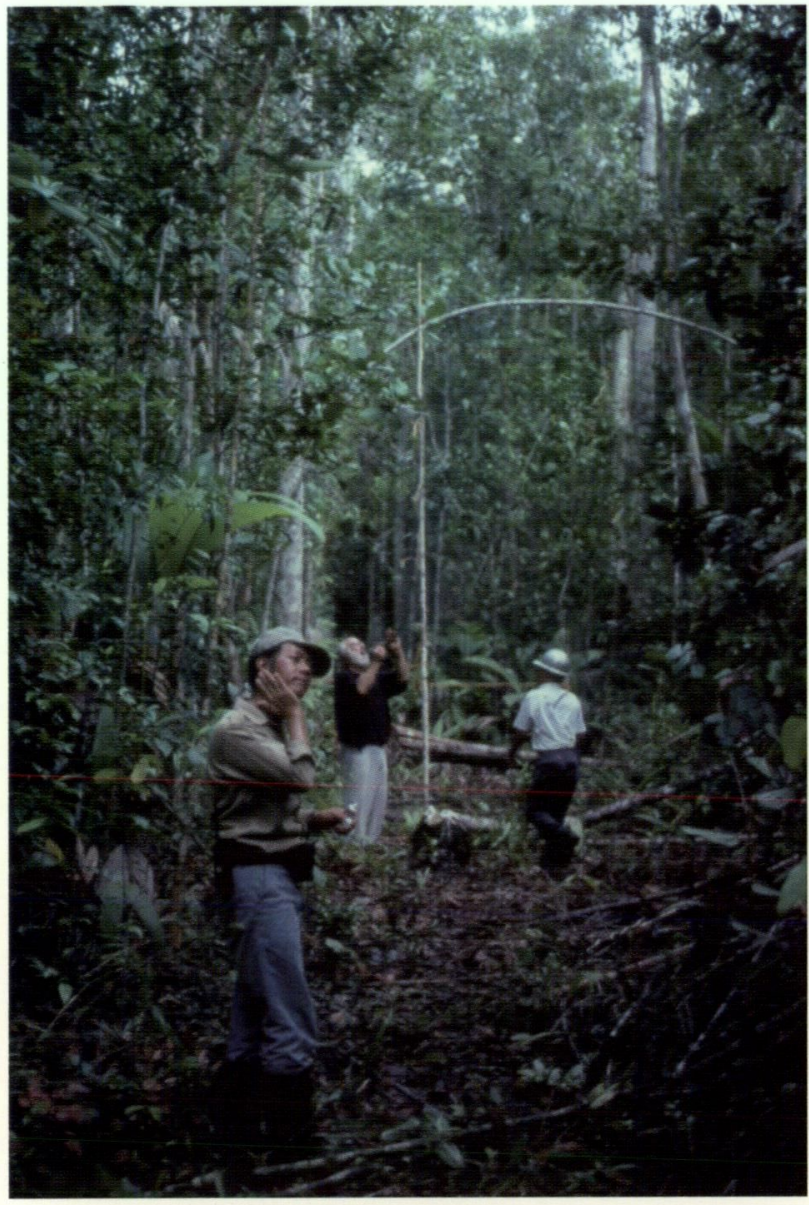

Figure 4 Rainforest near pit 8.
9. Ultra basic valley forest. Tall rainforest occurring in valleys of southern two-thirds of the island. Dominant trees include Dillenia, Horsfieldia, Buchanania, Eugenia and Clerodendrum (Figure 4).

10. Ultrabasic slope forest. Ranging from dense forest to open forest and scrub and occurring throughout the southern two-thirds of the island. Dominated by Gamau Ploiarium sessile, Calophyllum, Symplocos and Clerodendrum sp.

11. Ultrabasic ridge scrub. Ranging from areas of open shrubland and woodland to dense thickets. Occurring throughout the southern two-thirds of the island. Dominated by short and sparsely distributed Gamau Ploiarium sessile, Calophyllum articulatum, Planchonella oxyedra and Clerodendrum sp.

\section{Climate}

Gag Island has a tropical monsoon type climate, characterised by year-round moderate temperatures and high relative humidity. Its climate is influenced by the south-east trade winds from May to October and the north-west monsoons from December to April. The wet season (north-west monsoon) begins in October, peaks in December-January and may continue until April. Mean daily temperatures vary between about $21^{\circ}$ and $34^{\circ} \mathrm{C}$.

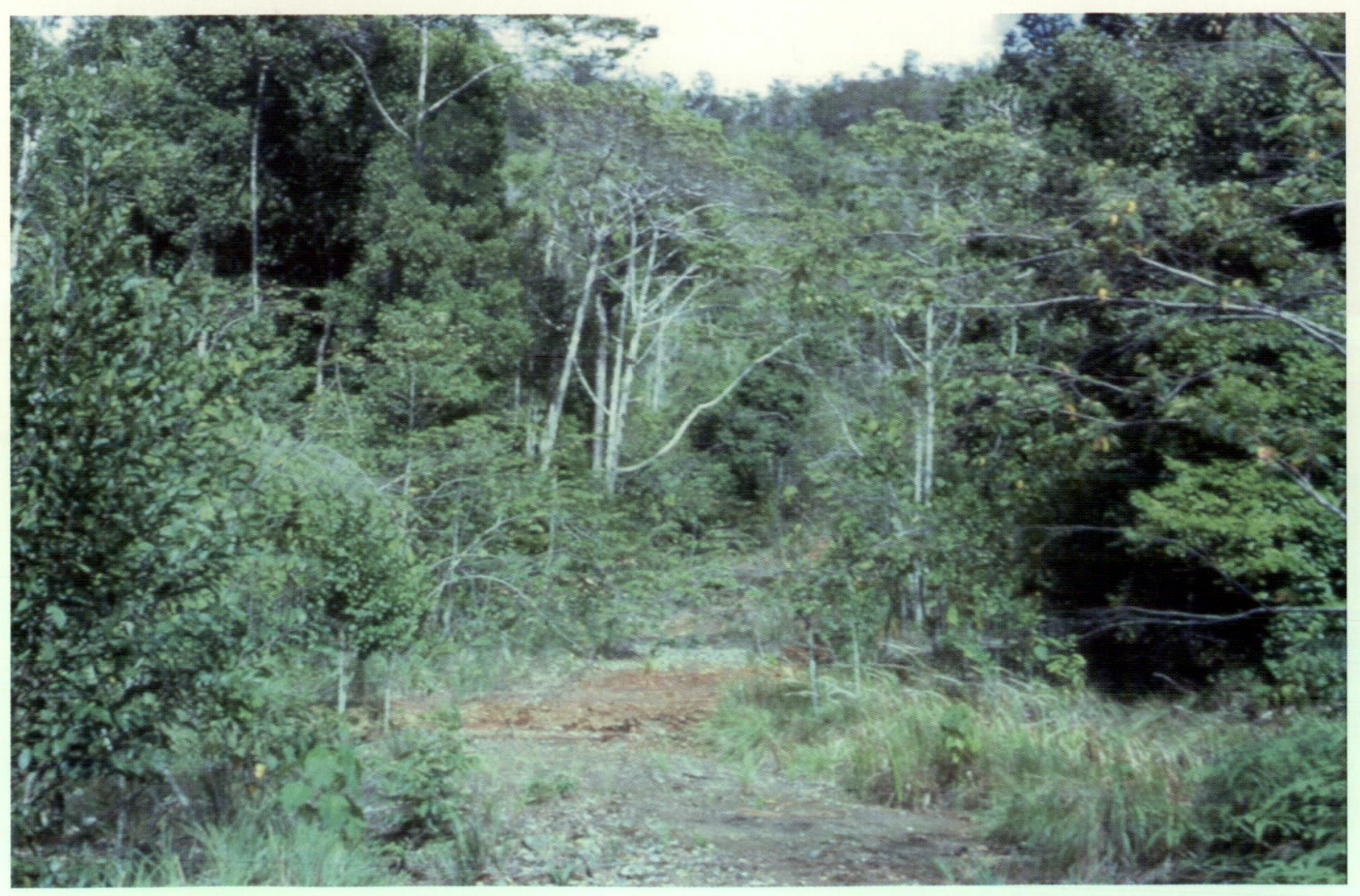

Figure 5 Disturbed volcanic forest along track to Turtle Beach. 


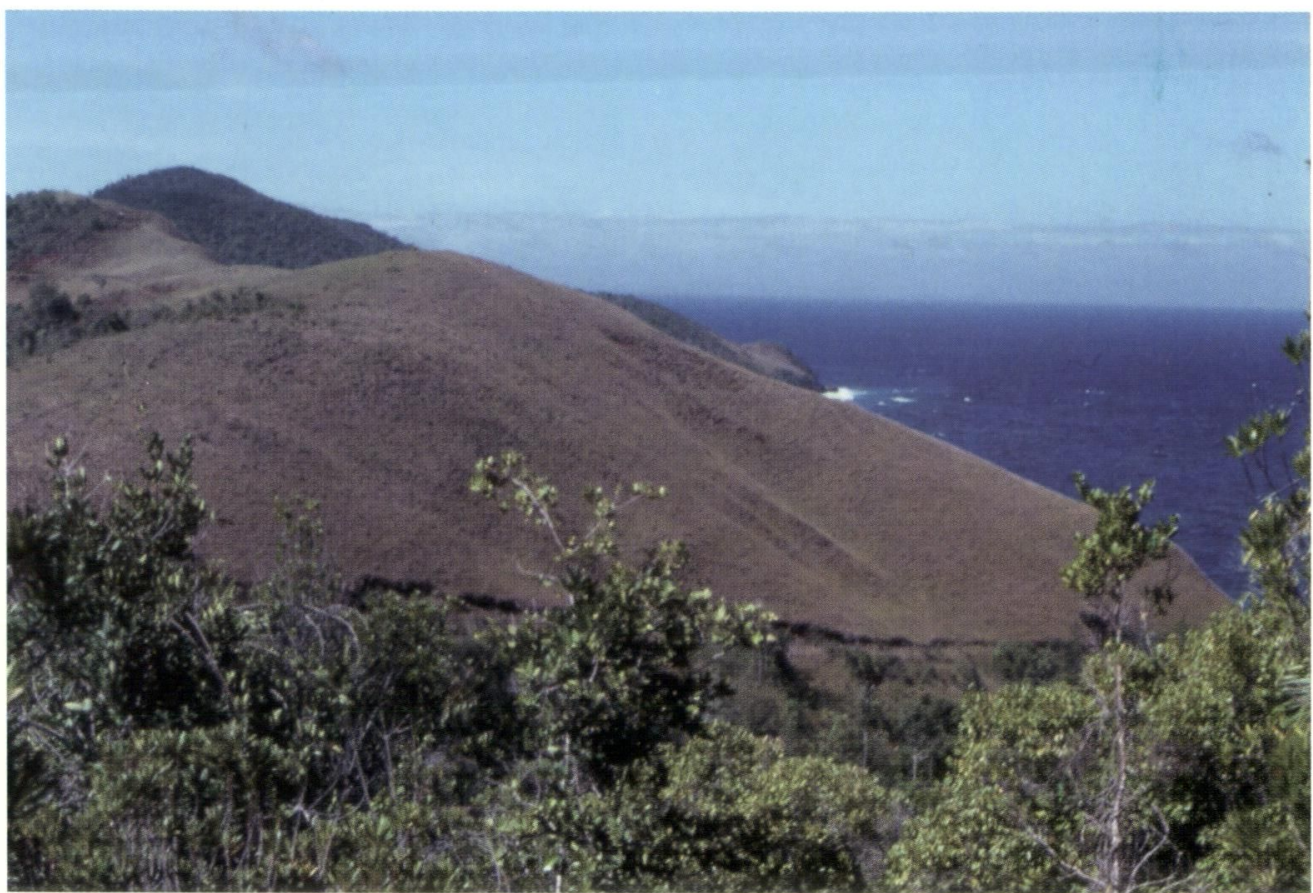

Figure 6 Grassland of Alang alang south of Camp 2.

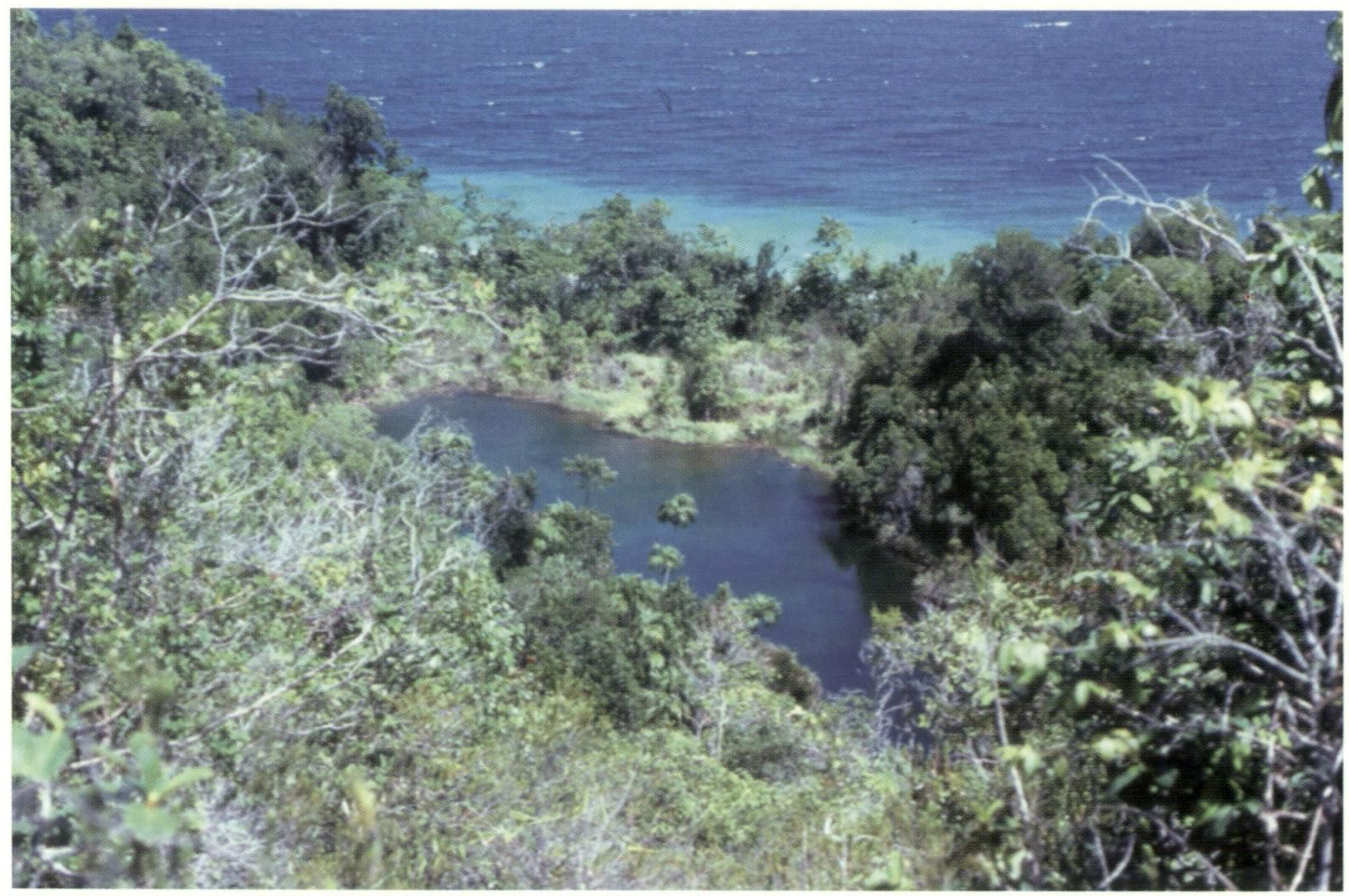

Figure 7 Lagoon, south-west corner of island.

\section{Ornithological History}

The ornithological history of Gag Island is rather sparse. The famous naturalist explorer A.R. Wallace spent several days on the island and collected a small number of specimens on Gag Island (Gagie) in early 1860s; Dr H.A. Bernstein also made a small collection on the island in 1863 and 1864; Dr J. Diamond and D. Bishop visited the island for a day in 1986. Apart from their records several species are listed for Gag Island by Peters (1967) and Sibley and Monroe (1990) in their world distributional lists but their source is however unknown; later F. Crome (1997) compiled a list of 39 species for Gag Island (based on literature records). As visits to Gag Island had been of short duration and very infrequent its avifauna was poorly known. This survey did not record eight of the birds previously listed for the island, but added a further 24 species (see Table $1)$. 


\section{ANNOTATED SPECIES LIST}

Classification and nomenclature follows Andrew (1992) and White and Bruce (1986) and Johnstone (2001).

\section{Fregatidae}

Fregata minor Great Frigatebird

Eight birds off Turtle Bay on 11 July, also listed for Gag Island in 1860s.

Extralimital range. Widespread in Indian and Pacific Oceans, also south Atlantic Ocean. Moderately common around Ambon and around Kai and Tanimbar Islands. (R.E. Johnstone unpublished data).

\section{Fregata ariel Lesser Frigatebird}

Four following coast north-west corner of island on 11 July and 10 over southern tip of island on 20 July. These are the first records for Gag Island.

Extralimital range. Breeding on tropical islands in Atlantic, Indian and Pacific Oceans. Widespread and moderately common in western Papuan region.

\section{Sulidae}

\section{Sula sula Red-footed Booby}

A beach washed skeleton found on north-east side of island in July. A wide ranging species occurring throughout tropical seas.

\section{Ardeidae}

\section{Egretta alba Great Egret}

One feeding on airstrip with two Intermediate Egrets on 14 July. Probably a scarce winter visitor from Australia or New Guinea, recorded patchily in Wallacea, with no evidence of breeding.

Extralimital range. Much of Old World from Europe and Africa east to Japan, Philippines, Solomons and New Zealand.

\section{Egretta intermedia Intermediate Egret (Lesser Egret)}

Moderately common. Single birds and groups (up to four). Mainly feeding on airstrip, edges of sago swamps, open pools, grassy areas around camp and occasionally seashore at creek mouths. Probably winter visitors from Australia. The first records for Gag Island.

Extralimital range. Africa south of Sahara and from Pakistan east to Japan, Philippines, Solomons and Australia. Widely distributed in Wallacea and New Guinea but little or no evidence of breeding and presumably most originating from Australia.

\section{Ardea sacra sacra Eastern Reef Heron}

Moderately common in ones, twos or threes. Resident. Mainly reef flats, rocky shores, beaches and tidal flats. Both white phase and dark phase birds recorded.
Extralimital range. Shores of east Indian Ocean and west and central Pacific. Widely distributed in the region including remote atolls.

\section{Ardea ibis coromanda Cattle Egret}

Historical records. Previously listed for Gag Island but not recorded during the July survey. Also recorded from northern Moluccas and Western Papuan, Waigeo and Yamna Islands.

Extralimital range. From southern and eastern Asia south-east to northern and eastern Australia and New Zealand. Only recently extended its range to include New Guinea. Records from northern Moluccas and Western Papuan islands. In eastern Wallacea dated specimens fall between SeptemberNovember.

\section{Accipitridae}

\section{Pandion haliaetus cristatus Osprey}

Moderately common. Ones and twos recorded over northern end of island, at Gambir Bay, at Camp Two and over lagoon at south-west corner of island. Previously listed for Gag Island and resident judging from a recently used nest in tree near airstrip.

Extralimital range. This subspecies ranges from Philippines and Sumatra south-east to Australia and New Caledonia. Widely distributed in coastal areas around New Guinea.

Taxonomy. The subspecies melvillensis is sometimes recognised for the birds from Indonesia, the Philippines, northern Australia and New Caledonia and cristatus for southern Australia and Tasmania. The smaller size of melvillensis is however doubtful judging from the wing measurements showing considerable overlap in White and Bruce (1986).

\section{Aviceda subcristata Pacific Baza}

Status uncertain. Previously listed for Gag Island but not recorded in July.

Extralimital range. New Guinea region, Bismarck Archipelago. Solomon Islands and northern Australia. An Australasian species extending into Wallacea with some marked geographical variation; in Moluccas subspecies $A$. S. reinwardtii from Seram, Ambon and Haraku and in western New Guinea A. s. stenozona.

\section{Haliastur indus girrenera Brahminy Kite}

Moderately common, usually in ones, occasionally twos. Coasts especially sheltered bays.

Extralimital range. Northern Australia, Moluccas, New Guinea and Bismarcks.

Taxonomy. Two forms recognised in Wallacea namely $H$. $i$. intermedius (Sulawesi and Lesser Sundas) and H. i. girrenera (Moluccas, and also eastern end of range). 


\section{Haliaeetus leucogaster White-bellied Sea-Eagle}

Moderately common in ones and twos. Two regularly seen over north end of island and Gambir Bay in July. Recorded over coasts and forest areas.

Extralimital range. India, Sri Lanka east to Bismarcks and Australia.

Accipiter novaehollandiae Grey Goshawk (Variable Goshawk)

Scarce or uncommon. One over open kebun on 13 July and one over camp on 18 July also previously listed for Gag Island but status on the island uncertain.

Extralimital range. Widely distributed in New Guinea, Melanesia and Australia with many local island forms. Eight subspecies recognised for Wallacea including A. n. griseogularis from Gebe Island and nine in New Guinea region.

\section{Aquila gurneyi Gurney's Eagle}

Probably a rare visitor from New Guinea. One observed twice over secondary forest on north end of island. Appeared to be attracted to roost of flying foxes (Pteropus). First record for Gag Island.

Extralimital range. New Guinea extending west to Moluccas. In Western Papuan islands recorded from Misool and Waigeo.

\section{Falconidae}

\section{Falco moluccensis Spotted Kestrel}

Uncommon. Ones and twos in July also historical records. Mainly open country on and around airstrip; also over cultivated areas and settlements. Easternmost records for Indonesia.

Extralimital range. Western Indonesia (Java, Moluccas, Sulawesi, Lesser Sundas).

Taxonomy. Two subspecies recognised F. m. moluccensis (Moluccas) and F. m. microbalia (Sulawesi region and Lesser Sundas). Birds from Gag Island appear most like the darker moluccensis populations.

\section{Anatidae}

Tadorna radjah radjah White-headed Shelduck

Uncommon. Two over beach near creek mouth north-east side of island on 17 July. First record for Gag Island.

Extralimital range. Moluccas, New Guinea region and northern Australia. Widely distributed but local on Western Papuan islands including Gebe.

\section{Megapodiidae}

\section{Megapodius freycinet freycinet Dusky Scrubfowl}

Common to very common. Mainly ones and twos occasionally small groups (up to five). Most numerous in beach vegetation especially on north end of island; also disturbed volcanic forest;

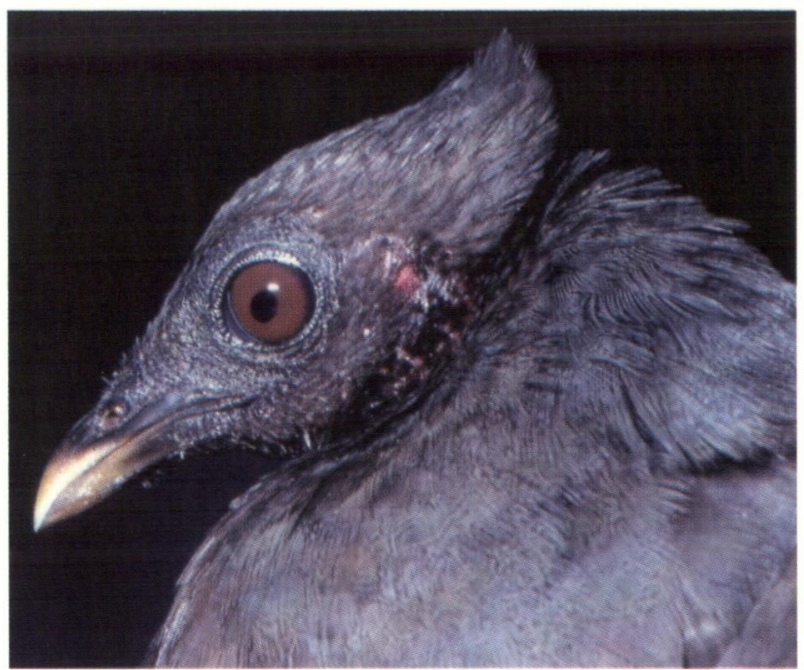

Figure 8 Dusky Scrubfowl Megapodius f. freycinet.

primary volcanic forest; sago swamps, edge of mangroves and once in dense Pandanus. Numerous active mounds in beach vegetation north end of island in July.

Extralimital range. Northern Moluccas, Western Papuan Islands (Waigeo, Batanta, Kofiau, Misool, Gebe, Gag) also Geelvink Bay Islands.

Taxonomy. The Gag Island population (along with Gebe, Waigeo, Kofiau and Misool) was placed in the nominate subspecies $M$. $f$. freycinet by Jones et al. (1995).

\section{Rallidae}

\section{Rallina tricolor Red-necked Rail}

Scarce of rare. Status uncertain possibly a migrant from New Guinea. One calling and another collected from sago swamp on north end of island. First record for Gag Island.

Extralimital range. Moluccas, Lesser Sundas, New Guinea region, Bismarck Archipelago and northeast Queensland. Recorded from Western Papuan islands (Misool and Waigeo).

\section{Scolopacidae}

\section{Numenius phaeopus variegatus Whimbrel}

Scarce visitor. One on rocks south end of island on 20 July. First record for Gag Island. Winter visitor and passage migrant.

Extralimital range. Breeding in north-east Siberia, and wintering from east India, Taiwan and Palau south to Australia and New Zealand. Common and widespread in Wallacea and New Guinea region mainly from August to April.

\section{Tringa hypoleucos Common Sandpiper}

Scarce visitor. Previously listed for Gag Island. In July single birds on rocks and edge of water on north end of island. A winter visitor and passage migrant. 
Extralimital range. Breeding in Europe and north and central Asia, and wintering in south Europe, Africa, south Asia and from Japan south to Australia. A common passage migrant to Wallacea and New Guinea.

\section{Arenaria interpres interpres Ruddy Turnstone}

Scarce or casual winter visitor and passage migrant. Two on reef flat north end of island in July. First record for Gag Island.

Extralimital range. Breeding in far north of North America, Europe and Asia and wintering from Japan, Hawaii and California south to South Africa, Australia, New Zealand and South America. Widely distributed in Moluccas and New Guinea region from March to November.

\section{Burhinidae}

\section{Esacus magnirostris Beach Stone-curlew}

Uncommon. Single birds observed on beaches and reef flats in July. First record for Gag Island.

Extralimital range. Coastal South-East Asia, New Guinea region to Solomon Islands, northern Australia and New Caledonia.

\section{Laridae}

\section{Sterna hirundo longipennis Common Tern}

Scarce visitor and passage migrant. Two on stack and later flying north off north-east side of island on 11 July. First record for Gag Island. This subspecies breeds in north-east Asia and winters from east India and Sri Lanka east to New Britain, Solomons and Australia.

\section{Sterna sumatrana Black-naped Tern}

Moderately common in July in ones, twos and small groups (up to six). Beaches, reef flats and coastal waters. First records for Gag Island.

Extralimital range. Breeding on islands in tropical Indian and western Pacific Oceans from Madagascar east to south China, Indonesia, New Guinea, northern Australia and Samoa. Widespread in Wallacea and western New Guinea coastal waters.

\section{Sterna fuscata Sooty Tern}

Single bird following the shoreline near Camp Two on 19 July 1997. First record for Gag Island.

Extralimital range. Breeding on tropical and subtropical islands in Indian Ocean and west Pacific and dispersing widely. Reported in small numbers in Moluccas and western New Guinea seas.

\section{Sterna albifrons sinensis Little Tern}

Scarce visitor and passage migrant. Three on beach and following shoreline near Turtle Bay on 17 July. First record for Gag Island.
Extralimital range. This subspecies occurs around shores of Indian Ocean and west and central Pacific. Moderately common and resident on islets in Wallacea and western New Guinea region.

\section{Sterna bergii Crested Tern}

Scarce. Single birds (probably this species on size) observed offshore near Camp Two in July. First record for Gag Island.

Extralimital range. Shores of Indian Ocean and west and central Pacific. Moderately common and resident on islets in Wallacea and western New Guinea region.

\section{Anous stolidus Common Noddy}

One edge of water on sandy beach near airstrip on 15 July. First record for Gag Island.

Extralimital range. Breeding on islands in tropical and subtropical Indian Ocean and west and central Pacific dispersing widely. Moderately common and resident in Moluccas and western New Guinea waters.

\section{Columbidae}

\section{Ptilinopus rivoli rivoli White-bibbed Fruit Dove}

Common throughout the island; in ones, twos and occasionally in small groups (up to five) at isolated fruiting trees. Mainly primary volcanic forest disturbed volcanic forest, ultrabasic valley forest and beach vegetation; less frequently in kebun vegetation and ultrabasic slope and ridge scrub. Most often observed feeding in canopy. Attracted to fruiting Gamau Ploiarium sessile.

Extralimital range. Moluccas including Kai Islands, Western Papuan islands (including Gebe, Gag, Misool) and most coastal islands; Geelvink Bay Islands; Eastern Papuan Islands and Bismarck Archipelago.

Taxonomy. Single adult male specimen from Gag Island is smaller (weight $95 \mathrm{~g}$ vs two males from Kai Islands 118-120 g), paler on upperparts and has a darker purple lower breast patch than specimens from Kai Islands and may represent a distinct island form. Forms a superspecies with $P$. solomonensis.

\section{Ptilinopus viridis pectoralis Claret-breasted Fruit- Dove}

Status uncertain. Not recorded in July 1997 but listed for Gag Island in historical data. Possibly very local or only a visitor to Gag Island.

Extralimital range. South Moluccas (Buru, Ambon, Saparua, Seram) Western Papuan islands (Kofiau, 'Gag', Gebe, Waigeo and Misool), lowlands of New Guinea, also Solomon Islands (separate subspecies $P$. v. lewisii)

Ducula myristicivora myristicivora Spice Imperial Pigeon

Common in ones, twos and small flocks (up to 


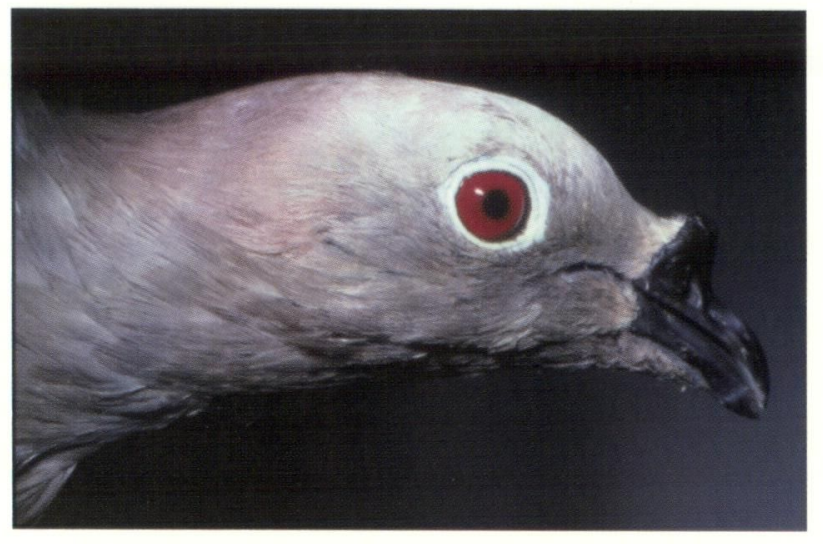

Figure 9 Spice Imperial Pigeon Ducula myristicivora

eight). Mainly primary volcanic forest, disturbed volcanic forest, ultrabasic valley forest and tall beach vegetation; less frequently in kebun and mangrove forest. Mostly seen feeding in the canopy on fruits and berries. Often observed perched on high bare branches or in powerful direct flight above the forest. Voice a loud gutteral 'urwoow'.

A small island species confined to eastern Moluccas, Western Papuan islands (including Gebe, Gag Island and Misool) also Geelvink Bay Islands.

\section{Macropygia amboinensis Slender-billed Cuckoo-} Dove (Brown Cuckoo-Dove)

Common to moderately common. Mainly in ones and twos occasionally small groups (up to four). Favours edges of forest habitats including primary volcanic forest, disturbed volcanic forest, ultrabasic valley and slope forest, also ultrabasic ridge scrub and beach vegetation. Attracted to fruiting Ploiarium in ultrabasic valley and slope forest. Commonly heard calling 'woo up' calls in most forest habitats. Display flights observed and a nest with one egg found in July.

Extralimital range. Sulawesi, Moluccas, all New Guinea islands and eastern Australia.

Taxonomy. Several well marked local subspecies in Moluccas. Single female from Gag Island does not match description of $M$. a. amboinensis or $M$. a. albiceps and further specimens are needed to confirm the subspecific status of the Gag Island population.

\section{Chalcophaps indica Emerald Dove}

Moderately common in ones and twos. Most observations in ultrabasic valley forest; primary volcanic forest and beach vegetation; less frequently in ultrabasic slope and ridge scrub and kebun. Favours forest edges and thickets, feeding on the ground on fallen fruits and seeds. First record for Gag Island.

Extralimital range. India to South-East Asia, New Guinea, Melanesia and Australia.
Taxonomy. This species has two distinct forms. In nominate indica males have a white forehead and supercilium and grey crown; C. i. longirostris is larger, has a vinous brown crown and front and no supercilium. The grey-crowned nominate form ranges from Kashmir through south and south-east Asia and the Philippines to the Moluccas, some Western Papuan islands (Gebe and Kofiau) and islands in Geelvink Bay (Numfor, Biak, Meos, and Num). The brown-headed form occurs in the Lesser Sunda Islands, eastern New Guinea, some Torres Strait islands and northern and eastern Australia. The two forms intergrade in the Lesser Sunda Islands and birds from Gag Island although most like the nominate race are also intermediate in a number of characters. Further work in the Western Papuan islands would help clarify the taxonomic status of these forms.

\section{Chalcophaps stephani stephani Stephan's Ground- Dove}

Locally moderately common but generally scarce. Mainly singly, occasionally in twos. Largely confined to beach vegetation and disturbed volcanic forest and edges of primary volcanic forest on north end of island; once edge of kebun. Mostly observed feeding on ground including two flushed regularly from freshly exposed earth and litter on a megapode mound in beach vegetation. First record for Gag Island and one of the few Moluccan islands where this species and $C$. indica are sympatric.

Extralimital range. Nominate subspecies C. S. stephani ranges from Kai Islands, New Guinea region (Aru Islands, Western Papuan islands (Misool, Salawati, Batanta and Waigeo) also other satellite islands including Admiralty and Bismarck and also Solomon Islands. Another subspecies C. $s$. wallacei in Sulawesi. Its present distribution suggests that it may have once inhabited the Moluccas but has been eliminated through competitive exclusion with $C$. indica which is continuing to expand its range. Further work in this region is needed to define the current distribution and status of these pigeons.

\section{Caloenas nicobarica nicobarica Nicobar Pigeon}

Scarce. Single birds observed near Camp Two in ecotone between mangroves and valley forest on 17 and 19 July. First record for Gag Island. Highly nomadic favouring small wooded islands and islets.

Extralimital range. Widely distributed on small forested islands from the Nicobar Islands, northeast Indian Ocean through the Sunda Islands, Philippines and New Guinea region to western Micronesia and the Solomon Islands. Patchily distributed in Moluccas and on some Western Papuan islands (Pecan Islands, Kofiau, Salawati and Waigeo). 


\section{Psittacidae}

Eos squamata squamata Violet-necked Lory

(Moluccan Red Lory)

Common. Mainly in pairs and small flocks (up to 10) occasionally larger flocks (up to 20). Attracted to flowering sago and coconut palms; also flowering and fruiting forest trees and shrubs. Mostly observed in primary volcanic forest, disturbed volcanic forest, kebun (including sago palms) and ultrabasic valley forest; less frequently in slope and ridge scrub. Often seen feeding in canopy taking flowers and fruits. One of the most conspicuous birds on the island.

Extralimital range. Northern Moluccas and Western Papuan islands (Batanta, Waigeo, Misool, Gebe and Gag).

Taxonomy. Four subspecies recognised namely: Eos squamata atrocaerulea (Moluccas); Eos squamata rinciniata (Moluccas); Eos squamata obiensis (Obi Island); and Eos squamata squamata (Western Papuan islands). Gebe Island is the type locality for the nominate subspecies where birds have the best developed collars. There are however slight differences between birds from Gebe Island and those from Waigeo and Misool Islands including a reduction in collar size. Judging from observations birds on Gag Island varied from having a distinct collar to little or no collar and may prove to be intermediate between Gebe and Waigeo populations.

\section{Micropsitta keiensis Yellow-capped Pygmy Parrot}

Scarce or uncommon. Only observed on north end of island. Two groups of three in and over disturbed volcanic forest on 17 July and two in dense beach vegetation near airstrip on 18 July. Also historical records and possibly seen by Diamond in 1986. These birds are extremely difficult to locate and may be more common than records suggest. Calls include a high pitched insect like 'tseeet'.

Extralimital range. Kai Islands, Aru Islands, Western Papuan islands (including Gag Island and Gebe) and western and southern New Guinea.

\section{Cacatua galerita triton Sulphur-crested Cockatoo}

Uncommon. In July only recorded in northern part of island. Ones and twos in primary volcanic forest and disturbed volcanic forest, also one observed flying over camp in Gambir Bay. Previously recorded for both Gag Island and Gebe Islands. Conspicuous and noisy and often seen perched on dead branches high up in canopy. Pair at nest hollow in huge tree in dense forest above Wapob River in July.

Extralimital range. Moluccas, New Guinea region including Aru and Western Papuan islands and Australia.

\section{Electus roratus polychloros Eclectus Parrot}

Common. Singly and in pairs. Largely confined to forest habitats i.e., primary volcanic forest, disturbed volcanic forest, ultrabasic valley forest, dense beach vegetation and less frequently in kebun and ultrabasic slope forest. Very conspicuous and noisy, often observed flying high above the forest or perched high on dead branches. Several females flushed and returned quickly to hollows in forest north end of island in July.

Extralimital range. Moluccas, Lesser Sundas and New Guinea region to Solomon Islands and northeast Australia.

Taxonomy. Three subspecies occur in the region namely: Eclectus roratus riedeli from Tanimbar Island, E. r. polychloros (type locality Gebe Island) restricted to Seram Laut, Tayandu and Kai Islands and some Western Papuan islands, and E. $r$. pectoralis on New Guinea mainland.

Geoffroyus geoffroyi pucherani Red-cheeked Parrot

Common. In ones, twos and small groups (up to five). Mainly forest habitats; primary volcanic forest, disturbed volcanic forest, ultrabasic valley forest, dense beach vegetation and less frequently kebun and sago swamps.

Extralimital range. Lesser Sundas, Moluccas, New Guinea region and north-east Australia.

Taxonomy. Marked geographic variation with 19 subspecies recognised by Peters (1961). The subspecies G. g. pucherani occurs in Western Papuan islands (Waigeo, Batanta, Salawati, Gebe, Gag Island and Misool) and north-western New Guinea east to about Etna Bay.

Tanygnathus megalorynchos megalorynchos Greatbilled Parrot

Uncommon. Usually in ones, occasionally twos, once three. Favours forested northern end of island. Primary volcanic forest, disturbed volcanic forest, ultrabasic volcanic forest and once in beach vegetation near airstrip. Also historical records for Gag. Favours small forested islands.

Extralimital range. Moluccas, Lesser Sundas and Western Papuan islands.

Taxonomy. Seven subspecies recognised. Nominate subspecies occurs on Talaut Islands, Sangir Islands, small islands off northern Sulawesi; northern Moluccas, Western Papuan islands (Waigeo, Batanta, Salawati, Gebe, Gag Island and Misool) and small islands off north-western New Guinea.

\section{Cuculidae}

\section{Cacomantis variolosus Brush Cuckoo}

Scarce or uncommon. Status uncertain possibly resident or winter visitors from Australia. Ones and twos in open beach vegetation near airstrip, 
disturbed volcanic forest and kebun (cultivated areas) in July. Two birds one a speckled immature regularly calling from prominent perch near airstrip in July. Also historical records for Gag Island and Gebe Islands.

Extralimital range. Malaya and Sumatra east to Bismarcks, Solomons and Australia.

Taxonomy. The nominate subspecies occurs in the region as a winter migrant from Australia; the subspecies $C$. $v$. infaustus is resident in southern Moluccas and western New Guinea region.

\section{Chrysococcyx minutillus Little Bronze Cuckoo}

One record. A single bird calling and flushed from sago swamp near camp on 13 July. The first record for Gag Island.

Extralimital range. From Malaya and Sumatra east to New Guinea and Australia.

Taxonomy. The Chrysococcyx 'malayanus' group of bronze cuckoos (including minutillus, russatus, rufomerus and crassirostris) contains a number of forms sometimes regarded as separate species. The distribution and taxonomic status of this group requires further study.

\section{Scythrops novaehollandiae Channel-billed Cuckoo}

Uncommon. In ones and twos. Mainly forested northern parts of island. Recorded in primary volcanic forest, disturbed volcanic forest, ultrabasic valley forest and kebun (cultivated areas). One being attacked by two Torresian Crows (a major host species) on 14 July. Status in region uncertain; breeding resident and also a winter visitor from Australia.

Extralimital range. From Sulawesi and Flores east to Bismarcks and northern and eastern Australia.

Taxonomy. The Sulawesi and Sula Islands populations are considered to represent an endemic subspecies.

\section{Caprimulgidae}

Caprimulgus macrurus schlegelii Large-tailed Nightjar

Locally moderately common but generally uncommon. Resident. In ones and twos (probably pairs). Mainly observed in northern two-thirds of island (including proposed mine site). Recorded in ultrabasic slope forest, ultrabasic ridge scrub, beach vegetation, kebun and sago vegetation and tracks in primary volcanic forest. Flushed during day from grid line tracks and roads with little or no cover and also from small clearings in dense forest. Regularly heard calling at night. Also observed hawking for insects at night around Gambir Bay camp area. First records for Gag Island.

Extralimital range. India, South-East Asia, the Greater and Lesser Sundas, Philippines, Moluccas, New Guinea region and northern Australia.
Taxonomy. Populations from the Western Papuan islands (Waigeo, Salawati, Batanta) and those from northern Moluccas are combined in the subspecies C. m. schlegelii.

\section{Apodidae}

\section{Collocalia esculenta Glossy Swiftlet}

Scarce. Four circling cliffs near Turtle Bay and several old nests in small cave on coast near Turtle Bay in July. First record for Gag Island.

Extralimital range. Bay of Bengal to south-west Pacific.

Taxonomy. Considerable geographic variation in Lesser Sundas, Moluccas and New Guinea region. Birds from Western Papuan islands are placed in nominate subpecies $C$. esculenta esculenta.

\section{Alcedinidae}

\section{Alcedo pusilla Little Kingfisher}

Status uncertain. Not recorded during July survey but collected on Gag Island by Bernstein in 1863. Possibly a scarce visitor to the island. Distribution and status in Moluccas and Western Papuan islands poorly known.

Extralimital range. Moluccas south to northern Australia and east to Solomon Islands.

Taxonomy. Populations in northern Moluccas often separated from New Guinea birds as race halmaherae. Taxonomic status of birds in Western Papuan islands requires review.

\section{Halcyonidae}

\section{Todiramphus sancta sancta Sacred Kingfisher}

Common winter visitor and passage migrant from Australia. In July recorded throughout the island in nearly all habitats i.e., coasts, beach vegetation, kebun; disturbed volcanic forest; primary volcanic forest; sago vegetation; mangroves; beach vegetation; ultrabasic valley and slope forest; and ultrabasic ridge scrub. Also collected by Wallace in 1860s. In Moluccas the Sacred Kingfisher is a regular, common, winter visitor arriving in AprilMay-June and departing mid September to mid October (Johnstone unpublished data). A few individuals may stay in their winter quarters.

Extralimital range. Breeding in Australia and partly wintering in islands to north, from Borneo and Sumatra east to Bismarks and Solomons.

\section{Todiramphus chloris chloris Collared Kingfisher}

Uncommon. Single birds observed at Turtle Bay, also on coast at Kampung Tua on north end of island in July; also collected by Wallace and Bernstein on Gag Island in early 1860s. Favours vicinity of coast but much less frequent than Beach Kingfisher.

Extralimital range. From Red Sea east through 
south Asia, Philippines, Micronesia, New Guinea region, northern Australia to Samoa and Tonga.

Taxonomy. Undergoes profound geographic variation and has been divided into about fifty subspecies. Birds from Western Papuan islands belong to nominate subspecies.

\section{Todiramphus saurophaga Beach Kingfisher}

Moderately common. Ones and twos. Coastal favouring exposed reefs, rocky slopes, beaches, beach vegetation and coconut groves. Often observed perched on dead branches, driftwood and rocks at edge of seashore.

Extralimital range. Moluccas, New Guinea region and North Melanesia. Largely a small island species.

Taxonomy. Birds from Western Papuan islands belong to nominate subspecies.

\section{Meropidae}

\section{Merops ornatus Rainbow Bee-eater}

Moderately common winter visitor and passage migrant from Australia. In July mainly in small parties (up to four) occasionally larger flocks (up to 20). Recorded feeding over kebun areas (coconut plantations); disturbed volcanic forest; beach vegetation and over ultrabasic valley and slope forest and camp area. First record for Gag Island. In Australia moving northwards in February-May and southwards in October-November. Australian birds ranging north in winter to Lesser Sunda Islands, Moluccu region, Western Papuan islands and New Guinea.

\section{Coraciidae}

\section{Eurystomus orientalis pacificus Dollarbird}

Common in July. Probably a resident and nonbreeding migrant from Australia. In July recorded in ones, twos and small flocks (up to 25). Observed in open areas around airstrip; over coconut plantations; forest edges and perched in forest canopy. One flock of 25 circling high over coconut plantation on 12 July. Also noted feeding on flying termites. The first records for Gag Island.

Taxonomy. The subspecies pacificus breeds in northern and eastern Australia and winters on islands to north (from Sulawesi and Lombok east to New Guinea). Other subspecies, including E. $O$. orientalis, from south and east Asia to Philippines, Bismarcks and Solomons.

\section{Pittidae}

\section{Pitta sordida Hooded Pitta}

Status uncertain. Not recorded in July 1997 survey but listed for Gag Island by Diamond and Bishop (1986). Possibly very local on Gag Island or perhaps only a casual visitor from nearby Gebe Island or migrant from Asia. This species favours lowland rainforest and mangroves and is generally silent and inconspicuous during dry season. A visit during the 'wet' would no doubt confirm its status on Gag.

Extralimital range. India, south-east Asia, Indonesia, New Guinea region including Western Papuan islands and Bismarck Archipelago.

Taxonomy. Forms a superspecies with $P$. maxima (of Moluccas) and P. superba (of Bismarck Archipelago).

\section{Hirundinidae}

\section{Hirundo rustica Barn Swallow}

Not recorded in July 1997, but listed in historical data. A non-breeding migrant from temperate northern hemisphere and likely to occur anywhere in the region. The subspecies gutturalis of eastern Asia and Japan winters in south-east Asia, Philippines, Sunda Islands, New Guinea region (including some Western Papuan islands) and northern Australia.

\section{Hirundo tahitica Pacific Swallow}

Moderately common (probably resident). Ones, twos and small groups (up to six) observed in July. Most frequent around habitation but also foraging over swamps and coastal areas. The first record for Gag Island.

Extralimital range. India, South-East Asia, New Guinea region, north-east Australia and Polynesia.

\section{Hirundo nigricans Tree Martin}

Moderately common. Most birds are probably winter visitors from Australia. In ones, twos and small flocks (up to eight) in July 1997. Mainly over open cultivated areas; coastal areas (including airstrip) and sago swamps. First record for Gag Island.

Extralimital range. Breeding in Australia (possibly also some breeding in Wallacea) and wintering in Lesser Sundas, Moluccas and New Guinea region.

Taxonomy. Two subspecies recognised namely: $H$. n. nigricans (from Australia) and H. n. timoriensis (resident on Timor).

\section{Campephagidae}

\section{Coracina papuensis papuensis White-bellied Cuckoo-Shrike}

Moderately common resident. Ones, twos and small groups (up to four). Mainly beach vegetation; cultivated areas (including coconut plantations and sago areas) and edges of forest (disturbed volcanic forest and ultrabasic valley forest). Also listed in historical data for both Gag Island and Gebe Islands and Misool, Salawati and Batanta.

Extralimital range. Moluccas, northern Australia, New Guinea region, Bismarck Archipelago and Solomon Islands. 
Taxonomy. The subspecies C. $p$. papuensis occurs in the Moluccas and western and northern New Guinea region.

\section{Corvidae}

\section{Corvus orru Torresian Crow}

Common resident. Mainly in twos and small groups (up to six). Beach vegetation; mangroves; cultivated areas (especially coconut plantations and sago swamps); also open areas and about habitation. Several old nests in tall trees near Turtle Bay. Also historical records for Gag Island and Gebe Islands. Four specimens collected for taxonomic studies.

Extralimital range. Northern Moluccas, eastern Lesser Sundas, Australia, New Guinea region and Bismarck Archipelago.

Taxonomy. Although Gebe Island birds have been allocated to the nominate subspecies, the taxonomic status of several populations in Moluccas, New Guinea and north-west Australia requires further study. There is considerable variation in calls and morphology (including eye colour) and the speciessubspecies limits need further appraisal.

\section{Pachycephalidae}

Pachycephala simplex Grey Whistler (also known as Grey-headed Whistler $P$. griseiceps)

Common resident, in ones and twos. Mainly forest habitats; primary volcanic forest; disturbed volcanic forest; ultrabasic valley and slope forest; mangroves and dense beach vegetation; less frequently in cultivated areas (coconut plantations and sago swamps). Mostly observed in mid-levels and canopy of forest.

Extralimital range. Moluccas, New Guinea region (including Western Papuan islands, Misool, Salawati, Batanta Gebe, Gag Island and Waigeo) and northern Australia.

Taxonomy. The Grey Whistler $P$. simplex has been recently treated as conspecific with the Grey-headed Whistler ( $P$. griseiceps). However there are some morphological and vocal differences between the two and this situation needs further appraisal. Populations of simplex-griseiceps within the Moluccas and Western Papuan islands also show considerable geographic variation; some being yellow on the abdomen and with an olive back, others lacking the yellow and being brown backed. Specimens from Gag Island ( $P$. griseiceps gagiensis) are strongly washed with yellow on the underparts and are quite different from the subspecies $P$. S. rufipennis of the Kai Islands. Further study of the species-subspecies limits within this group is required.

\section{Myiagridae}

Monarcha guttulus Spot-winged Monarch

Common resident. Usually in ones and twos.
Forest habitats: primary volcanic forest; disturbed volcanic forest; ultrabasic valley and slope forest; dense beach vegetation and less frequently in kebun and sago swamps. Favours the middle and lower levels of the forest.

Extralimital range. Endemic to New Guinea, the Aru Islands, Western Papuan islands (Misool, Salawati, Sagewin, Batanta, Wageo, Gag Island and Gebe), islands in Geelvink Bay, D'Entrecasteaux Archipelago and Louisiade Archipelago.

\section{Myiagra alecto chalybeocephala Shining Flycatcher}

Uncommon to moderately common resident. Singly and in pairs. Mainly primary volcanic forest; disturbed volcanic forest; beach vegetation; mangroves; overgrown kebun (coconut plantation); sago swamps; and less frequently in ultrabasic valley forest. Often in vicinity of water and forages mainly in the understorey.

Extralimital range. Moluccas, New Guinea region including Aru and Western Papuan islands (Kofiau, Misool, Salawati, Batanta, Waigeo, Gebe and Gag). Also Bismarck Archipelago and northern Australia.

Taxonomy. Several subspecies recognised within the region namely $M$. a. alecto (northern Moluccas); $M$. a. longirostris (confined to Tanimbar Archipelago); and M. a. chalybeocephala (Western Papuan islands and most of New Guinea).

\section{Muscicapidae}

\section{Muscicapa griseisticta Grey-streaked Flycatcher}

Listed for Gag Island by Crome (1997).

Breeds in south-eastern Siberia and winters in southern Asia and east to the Moluccas and western New Guinea. Recorded from several Western Papuan islands including Misool, Salawati, Batanta, Waigeo and Gebe.

\section{Rhipiduridae}

\section{Rhipidura rufiventris gularis Northern Fantail}

Moderately common resident. Usually in ones and twos. Mainly primary volcanic forest; disturbed volcanic forest; ultrabasic valley and slope forest; kebun (coconut plantation); beach vegetation; and sago swamps. Conspicuous and often observed sallying for insects at forest edges.

Extralimital range. Moluccas, Western Papuan islands (Salawati, Batanta, Waigeo, Kofiau, Gag, Gebe and Misool), New Guinea, Bismarck and Solomon Islands; Lesser Sunda Islands and northern Australia.

Taxonomy. Shows considerable geographic variation throughout the region especially in size and colour intensity; i.e., in width and spotting of the breast band, extent of superciliary spot, colour of outer rectrices and edging of wing coverts. Birds from Gag Island are similar in colouration to $R$. $r$. gularis of mainland New Guinea. 


\section{Rhipidura leucophrys Willie Wagtail}

Moderately common resident. Usually in ones and twos. Most plentiful in cultivated areas (coconut and sago plantations) and around habitation; also open or lightly wooded areas, beaches, edges of mangroves and around airstrip. One of the most conspicuous birds in the camp area at Gambir Bay. Historical records for both Gag Island and Gebe Islands.

Extralimital range. Moluccas, Lesser Sundas, New Guinea region, Solomon Islands and Australia.

Taxonomy. Birds from Gag Island match best with the subspecies melaleuca of New Guinea and the Solomons.

\section{Dicaeidae}

Dicaeum 'pectorale' Papuan Flowerpecker (Olivecrowned Flowerpecker)

Status uncertain. Listed in historical records for Gag Island and Gebe Islands (Crome 1997); an unidentified Dicaeum seen by Diamond in 1986; and a single Dicaeum making the typical 'Tsweet' call of Dicaeum hirundinaceum on edge of rainforest on 10 July 1997.

Extralimital range. D. pectorale occurs throughout New Guinea and most satellite islands.

\section{Nectariniidae}

\section{Nectarinia aspasia Black Sunbird}

Very common resident. Usually singly sometimes in pairs. Occurs throughout the island but favouring forests; primary volcanic forest; disturbed volcanic forest; ultrabasic valley and slope forest; dense beach vegetation; mangroves; and sago swamps; less frequently in ultrabasic ridge scrub and dense plantations. Feeds both in lower levels and canopy of forests. Not listed for Gag Island by most previous workers but listed for the island under Cinnyris sericea by Peters (1967), see also Mees (1965).

Extralimital range. Sulawesi, Moluccas, Western Papuan islands (Misool, Kofiau, Salawati, Batanta, Waigeo, Gebe and Gag) also throughout New Guinea and its satellite islands (Mees 1965).

Taxonomy. Gag Island birds belong to the nominate subspecies Nectarinia aspasia aspasia ranging throughout New Guinea and many satellite islands (Mees 1965).

\section{Nectarinia jugularis frenata Olive-backed Sunbird}

Very common resident. Usually in ones and twos; occasionally small parties at flowering trees and shrubs. Recorded throughout the island but favouring more open habitats than the Black Sunbird, i.e. mostly cultivated areas (kebun including coconut plantations; sago swamps; open beach vegetation and ultrabasic ridge scrub; also edge of forest habitats. Several pairs building nests, suspended from exposed roots, under low cliffs in July.

Extralimital range. South-east Asia, Moluccas and Sunda Islands, New Guinea region, north-eastern Australia and Solomons.

Taxonomy. Birds from Gag Island belong to the subspecies $N$. $j$. frenata occurring on New Guinea and satellite islands (also other subspecies in northern Moluccas and Australia).

\section{Estrildidae}

\section{Lonchura molucca Black-faced Munia}

Scarce. Two feeding on seeds from green grass heads on track in secondary forest near airstrip on 15 July and two in grass edge of airstrip on 19 July. First record for Gag Island and the Western Papuan islands.

Extralimital range. Sulawesi, Moluccas, Lesser Sunda Islands and several small islands off Bali and north-east Java.

\section{Sturnidae}

\section{Aplonis metallica Metallic Starling}

Common resident. Mainly in small flocks (up to 35 ), occasionally larger flocks (up to 50). Recorded in cultivated areas especially coconut plantations, gardens, disturbed volcanic forest, primary volcanic forest, sago vegetation, beach vegetation, ultrabasic forest and scrub areas and in mangroves. Noisy and gregarious. Observed feeding on flowering Albizia, fruits of Gamau Ploiarium sessile and flying termites.

Extralimital range. Moluccas, New Guinea region including most satellite islands, Solomons and Australia.

Taxonomy. Birds from Gag Island belong to the nominate subspecies $A$. m. metallica of Moluccas, New Guinea and north-eastern Australia.

\section{Artamidae}

Artamus leucorhynchus White-breasted

Woodswallow

One over beach vegetation near airstrip on $20 \mathrm{July}$ 1997. First record for Gag Island.

Extralimital range. Ranging from India eastward to New Guinea, Australia, New Caledonia and Fiji.

\section{DISCUSSION}

A total of 62 species (47 non-passerine and 15 passerine) were recorded during this survey. This includes 24 species not previously recorded for Gag Island and several that are important distributional records for the region. Despite its small size (56 $\mathrm{km}^{2}$ ) Gag Island has a relatively rich avifauna with the most conspicuous feature the high proportion of pigeons and parrots. It also contains a number of 
species that are restricted to small low islands and a number of species that range widely throughout the Oriental, Australian and New Guinea regions.

Few additional resident species could be expected, however more work during different seasons would no doubt add many visitors to the list. Crome (1997) listed 38 species previously recorded for Gag, and of these eight species were not recorded during this survey namely: Cattle Egret, Pacific Baza, Claret-breasted Fruit-Dove, Little Kingfisher, Hooded Pitta, Olive-crowned Flowerpecker, Barn Swallow and Grey-streaked Flycatcher. Of these the Barn Swallow and Greystreaked Flycatcher are both visitors from the northern hemisphere and would not be expected during July. The Cattle Egret has only recently expanded its range into the Western Papuan region and has a very patchy distribution. The Pacific Baza, Claret-breasted Fruit-Dove, Little Kingfisher and Hooded Pitta are often also very localised in distribution and may have been overlooked, or they may be only occasional visitors to Gag. The disparities between species previously recorded for Gag Island and the 1997 survey suggest that the land-bird fauna is in a state of flux with some species turnover. On the other hand it is difficult to judge how complete and accurate the historical records are for Gag. Some of the fruit-eating birds, especially the pigeons, are well known for their ability in colonising and moving between small islands to take advantage of flowering and fruiting trees.

Combining all records gives a total of 70 species. As with many islands in the Indonesian and New Guinea region non-passerine species outnumber passerines by a ratio of about 2:1 (Johnstone et al. 1996). The ratio in continental Australia and New Guinea is about 1:1. A breakdown of most of the Gag Island avifauna is as follows.

1. Marine species

Fregata minor

Fregata ariel

Sula sula

Sterna hirundo

Sterna sumatrana

Sterna fuscata

Sterna albifrons

Sterna bergii

Anous stolidus

2. Non-breeding winter visitors from Palaearctic Arenaria interpres

Numenius phaeopus

Tringa hypoleucos

Hirundo rustica

3. Winter visitors from Australia

Egretta alba

Egretta intermedia
Halcyon sancta

Merops ornatus

Eurystomus orientalis

Hirundo nigricans

\section{Visitors from New Guinea}

Aquila gurneyi

Rallina tricolor

\section{Resident species}

Egretta sacra

Pandion haliaetus

Haliaeetus leucogaster

Accipiter novaehollandiae

Falco moluccensis

Tadorna radjah

Megapodius freycinet

Esacus magnirostris

Macropygia amboinensis

Chalcophaps indica

Chalcophaps stephani

Caloenas nicobarica

Ptilinopus rivoli

Ducula myristicivora

Eos squamata

Cacatua galerita

Micropsitta keiensis

Geoffroyus geoffroyi

Tanygnathus megalorynchos

Eclectus roratus

Cacomantis variolosus

Chrysococcyx minutillus

Scythrops novaehollandiae

Caprimulgus macrurus

Collocalia esculenta

Todiramphus chloris

Todiramphus saurophaga

Eurystomus orientalis

Hirundo tahitica

Coracina papuensis

Rhipidura rufiventris

Rhipidura leucophrys

Monarcha guttulus

Pachycephala simplex

Nectarinia jugularis

Lonchura molucca

Aplonis metallica

Corvus orru

Gag Island is situated in the transition zone between the Austro-Papuan region to the east and the Wallacean faunal region to the west. Most of the resident species recorded for Gag Island also occur in the adjacent New Guinea lowlands and on other nearby islands. Judging from the distributions and subspecific affinities most of the birds have been derived from New Guinea. A small element including the Spotted Kestrel (Falco moluccensis) and Violet-necked Lory (Eos squamata) are Wallacean in origin. The zoogeographical 
Table 1 Species distribution in habitats during July 1997 survey

\begin{tabular}{|c|c|c|c|c|c|c|c|c|c|c|c|}
\hline Species & $\mathbf{M}$ & KB & DVF & PVF & SA & GR & MA & BV & UVF & USF & URS \\
\hline Fregata minor & & $x$ & & & & & & & & & \\
\hline Fregata ariel ${ }^{*}$ & $x$ & & & & & & & & & & \\
\hline Sula sula & $x$ & & & & & & & & & & \\
\hline Egretta alba & & & & & & $x$ & & & & & \\
\hline Egretta intermedia * & & $x$ & & & $x$ & $x$ & & & & & \\
\hline Egretta sacra & $x$ & & & & & & & & & & \\
\hline Pandion haliaetus & $x$ & & & & & & & $x$ & & & \\
\hline Haliastur indus & $x$ & $x$ & & & & & & $x$ & & & \\
\hline Haliaeetus leucogaster & $x$ & & $x$ & $\mathrm{x}$ & & & & & & & \\
\hline Accipiter novaehollandiae & & $x$ & & & & & & & & & \\
\hline Aquila gurneyi* & & & $x$ & & & & & & & & \\
\hline Falco moluccensis & & $x$ & & & & $x$ & & & & & \\
\hline Tadorna radjah* & $x$ & & & & $x$ & & & & & & \\
\hline Megapodius freycinet & & & $x$ & $x$ & $x$ & & $x$ & $x$ & & & \\
\hline Rallina tricolor * & & & & & & & & & & & \\
\hline Esacus magnirostris * & $x$ & & & & & & & & & & \\
\hline Arenaria interpres* & $x$ & & & & & & & & & & \\
\hline Numenius phaeopus* & $x$ & & & & & & & & & & \\
\hline Tringa hypoleucos & $x$ & & & & & & & & & & \\
\hline Sterna hirundo* & $x$ & & & & & & & & & & \\
\hline Sterna sumatrana * & $x$ & & & & & & & & & & \\
\hline Sterna fuscata * & $x$ & & & & & & & & & & \\
\hline Stema albifrons* & $x$ & & & & & & & & & & \\
\hline Sterna bergii * & $x$ & & & & & & & & & & \\
\hline Anous stolidus* & $x$ & & & & & & & & & & \\
\hline Macropygia amboinensis & & & $x$ & $x$ & & & & $x$ & $x$ & $x$ & $x$ \\
\hline Chalcophaps indica * & & $x$ & & $x$ & & & & $x$ & $x$ & $x$ & $x$ \\
\hline Chalcophaps stephani ${ }^{*}$ & & $x$ & $x$ & $x$ & & & & $x$ & & & \\
\hline Caloenas nicobarica* & & & & & & & $x$ & $x$ & & & \\
\hline Ptilinopus rivoli & & $x$ & $x$ & $x$ & & & & $x$ & $x$ & $x$ & $x$ \\
\hline Ducula myristicivora & & $x$ & $x$ & $x$ & & & $x$ & $x$ & $x$ & & \\
\hline Eos squamata & & $x$ & $x$ & $x$ & $x$ & & & & $x$ & $x$ & $x$ \\
\hline Cacatua galerita & & & $x$ & $x$ & & & & & & & \\
\hline Micropsitta keiensis & & & $x$ & & & & & $x$ & & & \\
\hline Geoffroyus geoffroyi & & $x$ & $x$ & $x$ & $\mathrm{x}$ & & & $x$ & $x$ & & \\
\hline Tanygnathus megalorynchos & & & $x$ & $x$ & & & & $x$ & $x$ & & \\
\hline Eclectus roratus & & $x$ & $x$ & $x$ & & & & $x$ & $x$ & $x$ & \\
\hline Cacomantis variolosus & & $x$ & $x$ & & & & & $x$ & & & \\
\hline Chrysococcyx minutillus* & & & & & $x$ & & & . & & & \\
\hline Scythrops novaehollandiae & & $x$ & $x$ & $x$ & & & & & $x$ & & \\
\hline Caprimulgus macrurus* & & $x$ & $x$ & & $x$ & & & $x$ & & $x$ & $x$ \\
\hline Collocalia esculenta * & $x$ & & & & & & & & & & \\
\hline Todiramphus chloris & $x$ & & & & & & & $x$ & & & \\
\hline Todiramphus sancta & $x$ & $x$ & $x$ & $x$ & $x$ & & $x$ & $x$ & $x$ & $x$ & $x$ \\
\hline
\end{tabular}

connections of Gag Island are largely with Waigeo and the western part of the Vogelkop.

Gag Island has no endemic species but contains a number of birds that exhibit significant geographic variation in the region including Grey Goshawk (Accipiter novaehollandiae), Dusky Scrubfowl (Megapodius freycinet), White-breasted Fruit Dove (Ptilinopus rivoli), Slender-billed Cuckoo Dove (Macropygia amboinenesis), Emerald Dove (Chalcophaps indica), Violet-necked Lory (Eos squamata), Red-cheeked Parrot (Geoffroyus geoffroyi), Little Bronze Cuckoo (Chrysococcyx minutillus), Torresian Crow (Corvus orru), Grey Whistler (Pachycepahala simplex), Shining Flycatcher (Myiagra alecto) and Northern Fantail (Rhipidura rufiventris). Specimens from Gag Island of Ptilinopus rivoli, Macropygia amboinensis, Chalcophaps indica, Pachycephala simplexgriseiceps and Corvus orru differ from neighbouring New Guinea and Moluccan populations and require further taxonomic assessment. Some of these may prove to be distinct island forms and if so, their future conservation on Gag Island will need to be addressed. 
Table 1 (cont.)

\begin{tabular}{|c|c|c|c|c|c|c|c|c|c|c|c|}
\hline Species & $\mathbf{M}$ & KB & DVF & PVF & SA & GR & MA & BV & UVF & USF & URS \\
\hline Todiramphus saurophaga & $\mathrm{x}$ & $x$ & & & & & & $x$ & & & \\
\hline Merops ornatus & & $x$ & $\mathrm{x}$ & & & & & $x$ & $x$ & $x$ & \\
\hline Eurystomus orientalis & & $x$ & $x$ & $x$ & & & & $x$ & & & \\
\hline Hirundo tahitica * & & $x$ & & & $x$ & & & $x$ & & & \\
\hline Hirundo nigricans * & & $x$ & & & $x$ & & & $x$ & & & \\
\hline Coracina papuensis & & $x$ & $x$ & & $x$ & & & $x$ & $x$ & & \\
\hline Rhipidura rufiventris & & & $x$ & $x$ & $x$ & & & & $x$ & $x$ & $x$ \\
\hline Rhipidura leucophrys & $x$ & $x$ & & & $x$ & & & $x$ & & & \\
\hline Monarcha guttulus & & $x$ & $x$ & $x$ & & & & $x$ & $x$ & $x$ & \\
\hline Myiagra alecto & & $x$ & $x$ & $x$ & $x$ & & $x$ & $x$ & $x$ & & \\
\hline Pachycephala simplex & & $x$ & $x$ & $x$ & $x$ & & $x$ & $x$ & $\mathrm{x}$ & $x$ & \\
\hline Dicaeum 'pectorale' & & & & & & & & & $\mathrm{x}$ & & \\
\hline Nectarinia aspasia & & $x$ & $x$ & $x$ & $\mathrm{x}$ & & $x$ & $x$ & $x$ & $x$ & $x$ \\
\hline Nectorinia jugularis & & $x$ & & & $x$ & & & $x$ & & & $x$ \\
\hline Lonchura molucca * & & & $\mathrm{x}$ & & & $x$ & & & & & \\
\hline Aplonis metallica & & $x$ & $x$ & $x$ & $x$ & & $x$ & $x$ & $\mathrm{x}$ & $x$ & $x$ \\
\hline Artamus leucorhynchus * & & & & & & & & $x$ & & & \\
\hline Corvus orru & & $x$ & & & $x$ & & $x$ & $x$ & & & \\
\hline
\end{tabular}

Legend. $M=$ Marine (coastal seas, stacks, reef flats and sandy and rocky shores); $\mathrm{KB}=$ Kebun (cultivated areas especially coconut plantations); DVF = Disturbed volcanic forest; PVF = Primary volcanic forest; $\mathrm{SA}=$ Sago swamps; GR = Grassland areas; $\mathrm{MA}=$ Mangroves; $\mathrm{BV}=$ Beach vegetation; UVF = Ultrabasic valley forest; USF = Ultrabasic slope forest; URS $=$ UItrabasic ridge scrub.

* New records for Gag Island.

A breakdown of the avifauna under each of the main habitat types is given below (where the status of a species is similar in two or more habitats it was included in each of them)

1. Beach vegetation: 32 species (12 passerine)

2. Kebun: 29 species (11 passerine)

3. Disturbed volcanic forest: 27 species (8 passerine)

4. Marine: 23 species (1 passerine)

5. Primary volcanic forest: 21 species (6 passerine)

6. Sago: 19 species (11 passerine)

7. Ultrabasic valley forest: 19 species (8 passerines)

8. Ultrabasic slope forest: 13 species (5 passerines)

9. Ultrabasic ridge scrub: 10 species (4 passerine)

10. Mangroves: 9 species ( 5 passerine)

11. Grassland: 4 species (1 passerine)

This gives an indication of the richness of each habitat type, but more particularly it shows the importance of the northern forest habitats and the ultrabasic valley forests.

Gag Island does support a number of species with high conservation importance (Collar et al. 1994) including Dusky Scrubfowl, Nicobar Pigeon, Sulphur-crested Cockatoo, Yellow-capped Pygmy Parrot, Great-billed Parrot and Eclectus Parrot. Most of these have declined in numbers in other parts of Indonesia due to capture for the wild bird market. Gag Island is also part of a region that provides important wintering grounds for many Australian landbirds including the Sacred Kingfisher, Rainbow Bee-eater and Tree Martin.

In order to minimise the impacts of mining on Gag Island it should be a priority for baseline surveys to identify and characterise the threatened habitats; establish and maintain sites for long term studies; continue to map species ranges and ascertain breeding bird densities in certain habitats and monitor changes in populations. It is also quite clear from this study that next to nothing is known about many of the other small islands in this Archipelago. An expanded programme of biological surveys and studies in the region is urgently needed so that biological information can be integrated into the region's development and conservation planning.

\section{ACKNOWLEDGEMENTS}

It is a pleasure to express thanks to Warwick Alliston and staff of BHP Gag Island for their help 
and hospitality during the July survey. I also gratefully acknowledge the support given by the Western Australian Museum, Perth, the Museum Zoologicum Bogoriense, Bogor and NSR Environmental Consultants Pty Ltd, Melbourne.

\section{REFERENCES}

Andrew, P. (1992). The Birds of Indonesia: a Checklist (Peters sequence). Indonesian Ornithological Society, Jakarta.

Beehler, B.M., Pratt, T.K., and Zimmerman, D.A. (1986). Birds of New Guinea. Princeton University Press, Princeton.

Crome, F. (1997). Ecological and biodiversity issues on Gag Island - results of a desktop study. A Report to NSR Environmental Consultants.

Collar, N.J., Crosby, M.J. and Stattersfield, A.J. (1994). Birds to watch2: the World List of Threatened Birds. U.K. Birdlife International, Cambridge.

Gray, G.R. (1862). Remarks on, and descriptions of, new species of birds lately sent by Mr A.R. Wallace from Waigiou, Mysol, and Gagie Islands. Proceedings of the Zoological Society of London 1861: 427-438.

Johnstone, R.E. (1994). Observations of Seabirds and Shorebirds in Nusa Tenggara (Lesser Sundas) and Moluccas, Indonesia. Western Australian Naturalist 19: 339-349.
Johnstone, R.E. and Sudaryanti (1995). The birds of Banda Neira, Moluccas, Indonesia. Western Australian Naturalist 20: 15-19.

Johnstone, R.E., Prawiradilaga, D. and Sudaryanti (1994). Distributional patterns of birds in Eastern Indonesia, particularly Australian-Indonesian seabirds, rainforest and mangal dwellers. Paper and abstract presented to symposium on 'Terrestrial Vertebrate Biodiversity in Indonesia'.

Johnstone, R.E., Jepson, P., Butchart, S.H.M., Lowen, J.C. and Prawiradilaga, D. (1996). The birds of Sumbawa, Moyo and Sangeang Islands, Nusa Tenggara, Indonesia. Records of the Western Australian Museum 18: 157-178.

Johnstone, R.E. (2001). Checklist of birds of Western Australia. Records of the Western Australian Museum Supplement No. 63: 75-90.

Jones, D.N., Dekker, R.W.R.J. and Reselaar, C.S. (1995). Birds families of the world The Megapodes Megapodiidae. Oxford University Press, Oxford.

Mees, G.F. (1965). A revision of Nectarinia sericea (Lesson). Ardea 53: 38-56.

Mees, G.F. (1972). Die Vögel der insel Gebe. Zoologische Mededelingen 46: 69-89.

Sibley, C.G. and Monroe, B.L. (1990). Distribution and Taxonomy of Birds of the World. Yale University Press, New Haven.

$\overline{\text { Manuscript received } 29 \text { July 1998; accepted } 10 \text { December } 2005}$ 